\title{
Peticiones varias
}

\section{Por Sara Uribe ${ }^{1}$}

1

Me piden que corrija las pruebas de un libro que no va a publicarse. Que señale las erratas. Que aporte mis posibles comentarios al diseño. Que.

Paso la madrugada leyendo galeras que bien podrían ser invisibles, contener lorem ipsum en lugar de las palabras que

El editor de la sucursal en Barcelona me escribe diciendo que no. Dice que no como quien arroja fruta podrida a la basura. No nos conocemos. Jamás he escuchado el timbre de su voz, pero en su correo me dice, enfáticamente, que no es viable compartir mi libro de manera gratuita en internet. Que está mal, muy mal, tan mal que por eso el libro no puede publicarse. Tan mal que debo pedir perdón de rodillas al copyright. Tan mal que por eso en España está prohibido sacar fotocopias de los libros. Que iré a la cárcel. Que debería hacer penitencia por el resto de mis días.

Bueno, no. No dice eso. Exagero. Sólo me escribe un escueto mail en el que afirma que el libro no puede publicarse con una licencia creative commons.

Lo que yo sigo sin entender es por qué me piden que revise y comente la versión casi definitiva de un libro que no quieren que, sin su permiso, sin el permiso de la editorial, pueda reproducirse ni circular libremente ni descargarse ni

El editor en México suscribe las palabras de su abogado: lo que yo le propongo no es serio ni legal. Me dice que él creía que yo era una persona seria. Eso dice: una persona seria, una persona

1 Sara Uribe (Querétaro, Querétaro, 1978). Poeta y ensayista mexicana. Licenciada en Filosofía. Directora del Archivo Histórico de Tampico. Publicó Lo que no imaginas (2004), Palabras más, palabras menos (2005), Antígona Gonzalez (2012) y Siam (2012). Su obra ha sido recopilada en diversas antologías. 
legal. Una persona que no propone disparates editoriales a diestra y siniestra.

Pero yo, que ni seria ni legal, no les comprendo. No atisbo para qué, entonces, formar un libro, mandar las pruebas, pedir correcciones. No concibo que un libro, que un régimen de distribución, pueda causarles tanto prurito. No discierno que sin su consentimiento no podamos. No acepto que me digan, que me exijan que sea seria y legal, cuando mejor debían decir

Me piden que firme un contrato donde acepto, no sólo cederles el alma que no tengo, sino el alma de la descendencia que tampoco tengo ni tendré. Me piden que lea, pero en verdad esperan que no lo haga, las cláusulas de un documento legal que a veces ruge, y otras tantas muerde, como el león que es. Leonino el contrato y leoninos los editores. Me piden/me aclaran, que no me exigen, que nadie me obliga, que soy libre, si quiero, de no firmarlo, pero que haga el favor de firmarlo de una puñetera vez, porque el tiempo es oro y el contrato leoncillo incipiente. Me piden que los nombre mis agentes, que les ceda, a falta de alma, mi agencia, mi agenda, mi. Sin especificar cuántos años durará, me solicitan amablemente rubrique al calce y en los lugares donde aparece mi nombre. No dejan de puntualizar que, si la empresa pudiese, por alguna razón ignorada, caer en manos de terceros, éstos, a quienes desconozco, quienes, hasta ahora hipotéticos, pero en algún momento reales, posiblemente muy reales, serían los poseedores de los derechos de mi obra para adaptaciones, para reimpresiones, para ofrecerla a terceros, para traducirla a otros idiomas, en suma: para hacer con ella lo que les dé su chingada y teórica, pero potencialmente tangible, gana. También me sugieren que no pregunte, que no indague, que no me queje. Me aseguran y me juran que todos los demás autores han firmado sin chistar. Porque no me digan / que ustedes / no han firmado / sin leer / contratos así.

\section{3}

Me piden

les escriba textos

sin recibir a cambio pago alguno.

Me piden 
les permita

darme la oportunidad

de que lo que escribo

sea leído por otros.

¿Qué cómo que quiero un pago por eso?

Que casi casi

yo debería pagarles

por darme tan loable oportunidad.

Me piden que conteste sus correos a deshoras

que haga caso inmediato de sus comunicaciones

que atienda sus llamadas, que

cuanto antes, cumpla con mi deadline.

Me abordan por correo

por dm, por inbox de Facebook

o la mensajería de Instagram

que ni siquiera sé cómo se llama.

Por último

consiguen mi WhatsApp

y me mandan mensaje tras mensaje

para apurarme

presionarme

invitarme

requerirme

sugerirme

conminarme

apercibirme

insinuarme

y cuestionarme

que si ya

que si por fin

que si ahora sí

voy a mandarles

su texto

porque

ay

cómo les urge

pero yo 
que sé

cómo hacer

oídos sordos

no me entero

de verdad que no me entero

de nada.

Me piden que no sea hipócrita, que les diga que también hay textos, lecturas, charlas, dictámenes o conferencias por las que sí me pagan. Es cierto, no voy a mentirles. Sólo añadiré que para poder cobrar mis honorarios, mis empleadores me piden: la credencial para votar de mi recibo del agua, el comprobante de domicilio de mi curp, la constancia de situación fiscal de mi estado de cuenta bancario, el cv de mis facturas, la fe de bautismo de mi fe de bautismo (ay, y yo que ni fe de nada tengo). Me piden los documentos una y otra vez y una y otra vez los entrego y los vuelven a perder. Me piden que vaya a firmar los contratos que ya les había firmado, que les escanee y reenvíe y refirme y recontrafirme. Me piden que espere unos días, unos meses, casi un año y luego me piden que les vuelva a enviar todo de nuevo para empezar el ciclo una vez más. Me piden que aguarde los pagos hasta que éstos se conviertan casi casi en la jubilación simbólica que no tendré. Me piden

que tenga paciencia

porque

el recurso

ya casi

deveritas

va

$\mathrm{a}$

bajar.

Iba a decir, a escribir, también, que me piden poemas inéditos, siempre, pero eso ya lo dijo y escribió, antes y mejor, Fabio Morábito. 